\title{
"ECO-INFILL" AS AN ALTERNATIVE STRATEGY FOR POST- INDUSTRIAL LANDSCAPE IN THE LIGHT OF CLIMATE CHANGE: THE CASE OF BELGRADE SHIPYARD *
}

\author{
$U D C$ 551.583:629.12(497.11)=111
}

\author{
Ana Nikezić, Nataša Janković \\ University of Belgrade, Faculty of Architecture, Serbia \\ ana.nikezic@gmail.com
}

\begin{abstract}
At this moment, and under the circumstances that surround us, we have recognized as a definite global challenge the problem of climate change, and in general, the ecological misbalance of cities. In an attempt to meet this challenge, we will try to discuss possibilities of implementing the "Eco-Infill" strategy (fragments of nature incorporated into abandoned artificial environment) as a viable, somewhat "alternative", urban development strategy.

The contemporary matrix of the post-industrial urban landscape is dotted with large and small fragments of abandoned spaces, which need to be incorporated into the city texture. Belgrade is a city with a potential, one of the larger capitals of the region, standing on the threshold of the European Union and undergoing an intensive process of political, economic and social transition. Similar to other large cities, it was previously an industrial city, but is now increasingly relying on the tertiary sector, promoting itself through its geographical, morphological, and cultural advantages. The consequences of privatization during transition and an exceptionally long and difficult political and economic crisis produced Brownfield and other abandoned spaces of the city centre with a complicated proprietary-ownership status, and no realistic guidelines for a much needed regeneration of the city centre in terms of contemporary problems linked to ecological, social and cultural values.

In this article, there is a tendency to define principles on which the transformation of these abandoned places is based on and to try to apply these strategies onto the Belgrade shipyard on the river Sava. If we accept the previously set general views, these spaces can become crucial in developing a strategy for mitigation and adaptation to climate change. Although these effects are primarily aimed at confronting climate change, they are bound to upgrade the quality of life and offer new life styles, potentially affecting all aspects of urban life, considering that most of the eco-infill we are talking about consists of active public space.
\end{abstract}

Key words: post-industrial landscape, Brownfield, climate change, Belgrade shipyard.

Received November 14

* Acknowledgement. This paper was realized as a part of the project "Studying climate change and its influence on the environment: impacts, adaptation and mitigation" (43007) financed by the Ministry of Education and Science of the Republic of Serbia within the framework of integrated and interdisciplinary research for the period 2011-2014. 


\section{INTRODUCTION: BROWNFIELD vS. CLIMATE CHANGE}

In the era of urban regeneration, the parameters of environmental sustainability and enhanced awareness of climate changes significantly change relation between forces in the conflict of social-economic requests and cultural-historical values of place on the one side, and environmental requests and needs of adaptation and mitigating the effects of climate changes on the other side.

The revival and recycling of Brownfield has already been justified by many studies (Dixon at al., 2007), and is one of the leading desirable stakeholders in the process of urban regeneration of the city centre. By creating more serious legislative which directs regeneration towards the respect of environmental aspects, the need for recycling abandoned spaces into city green open public spaces emerges (Loures et al., 2006). The contemporary studies promote its transformation into open green spaces (Doick et al., 2009) as an impetus to the environmental sustainability of city center by: a) providing recreational spaces near the dwelling places, b) reducing traffic and c) creating environmental stations which foster local micro climate and biodiversity.

Instead of seeing Brownfield areas as an opportunity for developing the city by building what we already have (housing blocks and centers of commerce), they can be gradually developed, connected and incorporated into existing green areas of the city, and developed into elaborate networks, thus offering new possibilities of global development by affecting the city as a whole. Although these effects are primarily aimed at confronting climate change, they are bound to upgrade the quality of life and offer new life styles, potentially affecting all aspects of urban life, considering that most of the eco-infill we are talking about consists of active public space.

In the past few years, the position of Brownfield as spatial potential of the cities to be involved in the global process of adaptation and mitigation of the effects of climate changes was additionally discussed about (Doick et al., 2009; Lafortezza et al., 2006, Loures et al., 2006). Transformed and affirmed Brownfield complex would be able to provide balanced relation between compactness and density, could serve as water, soil and other natural resources reservoirs, could become healthy land suitable for planting and ambients protecting the immediate environment micro climate, as well as a place that can compensate for greenfield and thereby reduce the need for traffic in the sense of the relation between man and greenfield, thus having a positive effect upon entire condition of the environment.

In the text by Hamin and Gurran (Hamin, Gurran, 2009) Urban form and climate change: Balancing adaptation and mitigation in U.S. and Australia the solution of the relation between mitigation and adaptation has been set through urban green open spaces which can satisfy both aspects of climate changes. Mitigation of the climate changes in densely built urban environments requires reduction of motor vehicle use and energy consumption in buildings while adapting to climate changes requires open spaces available for managing elements, migrations of various species and urban cooling, among other goals.

These open green spaces must be designed to meet diverse goals, such as urban agriculture (Viljoen, ed., 2005), establishment of green and water areas in the structure of the eco-park as an important resource for unexpected climate changes or other protective systems against floods (Yarinski, 2008). The larger blocks of open space can form a space for recreation and leisure, as well as space that can be adapted to changing water levels in 
the midst of climate change, while such green belts would be able to strengthen the internal relations of the neighborhood. It is also necessary for the buildings to use more natural energy resources such as solar or wind energy (Ewing et al., 2008), it is necessary to take care of preservation of biodiversity, specific species (Doick et al., 2009), in order to form vital, healthy and harmonious form of urban structure.

It can be concluded that with creation of the network of green spaces by repetition of the strategy of greening the Brownfield in urban city core, the reduction of harmful effects of the urban city life and built structure on climate conditions can be influenced, but also basic principles for some new sustainable strategies of development of modern urban city can be created.

Natural landscape in urban space would enable revival of the natural processes, would regenerate entire city districts and zones, create multifunctional open spaces which are available and accessible and would promote sustainable development of the city. Many landscape architects have proved through their designs a solution in creating a culturally stimulating landscape recycling unutilized waste from the abandoned industry.
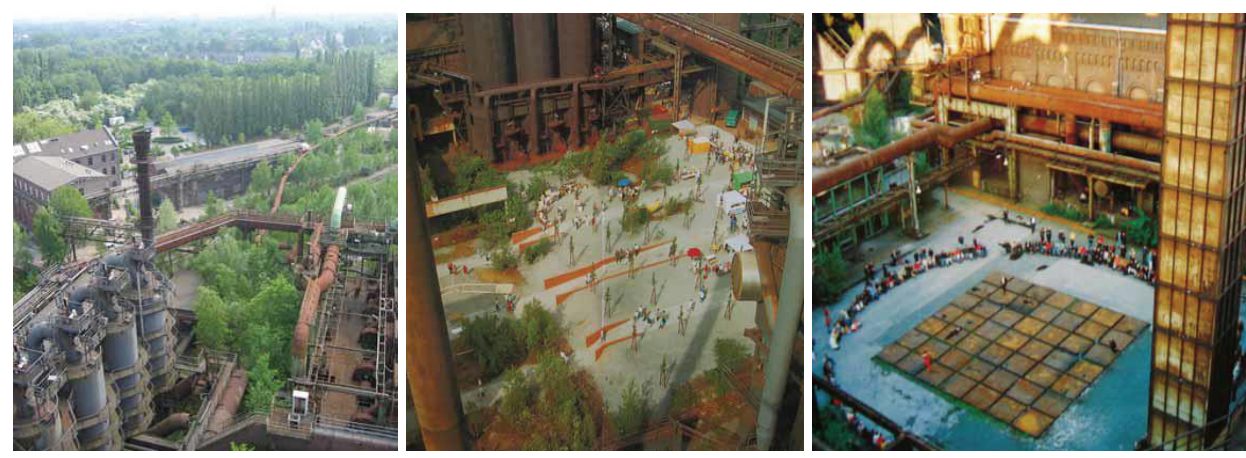

Fig. 1, 2, 3. Landschafts park, Duisburg Nord, Germany, 1991. Peter Latz + Partner

Perceived from the viewpoint of adaptation to the climate changes and mitigating their effects, Brownfield, by its size and position in the central and especially coastal zone of the city, then by its significance as a spatial resource of un-built city structure, as well as with its infrastructural potential, presents a desirable stakeholder in the process of climate changes, as well as the challenge in the practice of its regeneration. Therefore, they might be seen as a viable resource for coping with climate change.

In the process of mitigation

- recycling and using the existing infrastructure,

- clearing and healing land, air, and water and reducing atmospheric pollution,

- large potentially planting areas,

- empty space that offers the possibility of airing the immediate environment, and the conservation of energy through cooling and shading,

- forming of microclimate comfort zones; 
In the process of adaptation

- using surface and ground water, as well as soil as potential resources (in the case of floods and other extraordinary situations caused by climate change),

- reducing storm effects,

- leaving large areas as natural and unbuilt (reduce emissions and greenhouse gases);

In the process of adaptation and mitigation as an active system

- creating natural habitat

- inherited industry can be used as a cleaner drive for garbage, wastewater, recycling, as a support the creation of ecological systems, power generator and biofuels

- forming spaces for relaxation, recreation and social interaction.

\section{ECO-INFILL: \\ PRINCIPLES AND PROGRAM ELEMENTS}

It is necessary to identify the way in which to interpret historical and cultural significance of the location and to understand the ways in which ecology and design could mutually shape alternative relations between people, place, nature and inherited structure as to define architecture of invention rather than restoration, revival rather than preservation, vitality rather than scenario, adaptability rather than transformation. The question has been asked regarding what eco-infill strategy has to offer.

Depending on the manner of usage it can be a green oasis or a gathering place, an ecological station or a recreational center. Depending on the size it may represent new urban center significant for wider environment, or even a common neighborhood area or a smaller individual garden. It seems that, regardless of its size, significance or manner of usage, these areas in their definition have to incorporate two, at the first glance, contradictory entities: the natural and the urban condition. The urban condition is determined through the phenomenon and typological determinants of Urban gardens, and the natural condition through the phenomenon and basic principles of Terrain vague (terrain vague) (De Sola Morales, 1995), namely Vague park (vague park) (Kamvasinou, 2006).

In interpolation of these two phenomena, the Urban garden as a finished product and the Vague park as a generator of natural processes lies the essence of Eco-Infill strategy. That is a place where recreation is enabled but not strictly regulated, where the space is designated for walks and relaxation, but also to preservation of biodiversity, where the inherited structure was revitalized through recycling process and is in service of implementation of ecological potentials of the environment.

Urban garden represents the place for recreation (active or passive), place of rest and leisure but also a spatial polygon for various cultural and educational events. In the prospect of Brownfield, Urban garden mostly emerges in the form of open space with the elements of park and recreational areas and quite often with specific spaces for public activities such as concerts and bazaars. The space of urban garden, in some cases is treated as a kind of oasis in the city, with cultivated vegetation that acts as the antithesis to the built environment. In other cases the situation is opposite, when the solid surface overwhelms the soft one, and this space looks more like a greened square than a park. Urban garden is the product of urban design, attractive and likable; a dynamic break incorporated in the contemporary life of the immediate environment. 

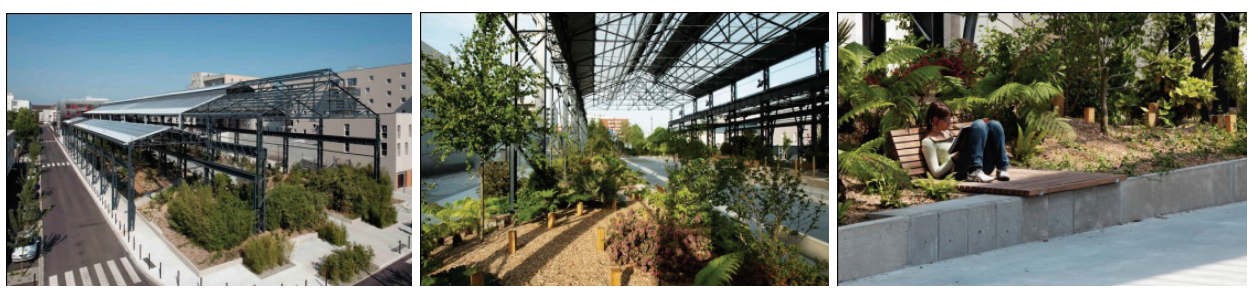

Fig. 4, 5, 6.Jardin des Fonderies, Nantes, France, ADH Doazan+Hirschberger, 2009.

Vague park (,Vague Park") is easy accessible and open system, spontaneously created, diverse and integrative, "vague" piece of land in the city, a part of the nature complementary to the phenomenon of the urban from the essence of its opposition. It is the space which is based on the principles of preservation of the inherited character of landscape, resulting in collision of the natural and the urban, and very often in the process of abandonment It comprises preservation of the space with all its characteristics, promotes the process of environmental sustainability, recycling and agriculture through various art projects and education, primarily through the design of space as the generator of urban transformations, not the products. That is a place characterized by incompleteness, less strict control of conditions of use, and the layers of memory and atmosphere that never forgets abandonment as an integral part of the history of the place.

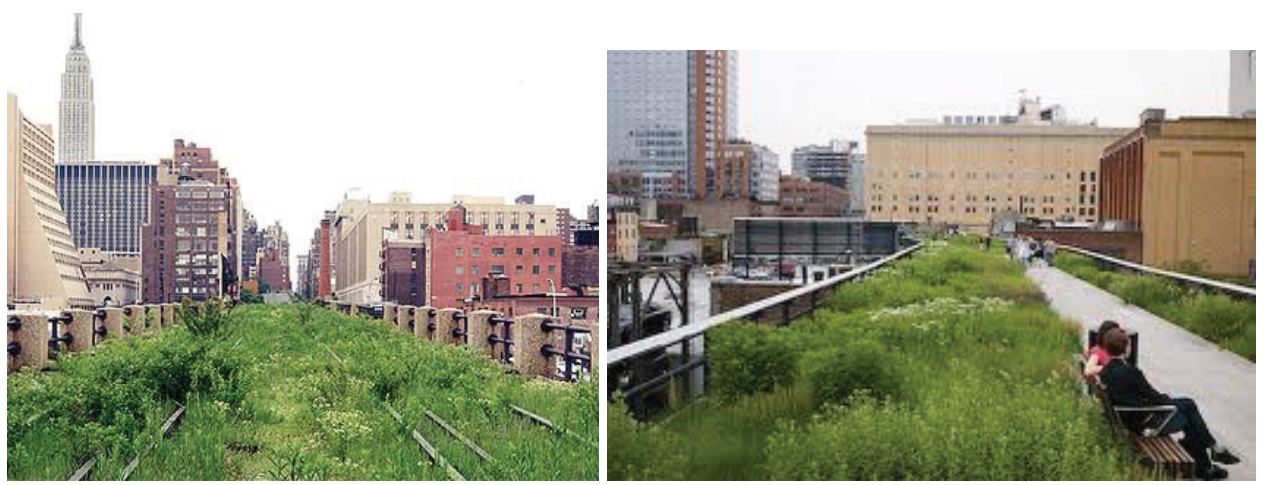

Fig. 7, 8. High Line, New York, USA, Diller Scofidio + Renfro, 1999.

Eco-infill strategy therefore proposes a model of public open space which on one side meets the need of urban life style and on the other side protects the inherited character of the landscape. It originates in the interpolation of the elements of activity and architectural language of urban garden and principles of conception of Vague park shaping a distinctive cultural landscape as an alternative approach to shaping public urban open space. This is an open public space in which in confronting nature and city, as well as the inherited structures and natural resources, offers a sustainable solution that can and should adapt together with preferences of its users and in accordance with climate change.

Any attempt to define basic principles that Eco-infill is based on has to involve principles of economic development, social sustainability (availability, accessibility, attractiveness, involvement), environmental development (biodiversity, micro-locations, recycling, 
energy sources), maintaining of the natural environmental resources (water, land, air) as well as reducing the harmful effects and adaptation to upcoming climate changes, and never the less it comprises their interdependence at the local community level.

Eco-infill is based on the principle of preserving the abandonment whether it concerns the inherited industrial structure or its natural characteristics, the principle of uncertainty, in the sense of making the space free of excessive completeness and control, and the principle of spontaneity, in terms of social openness, accessibility and the potential of involvement of local communities into the life of once abandoned space. The power of this space lies in the freedom and openness, incompleteness of the process (interaction of the natural and inherited built infrastructure), as well as the permanency of change (the uncontrolled growth of nature, the growth process rather than completed forms) that are provided by self-sustainable local community.

It seems that eco-infill leaves enough space to develop recreation and spectacle at the same time, to enable biodiversity, to simultaneously protect industrial legacy and preserve the landscape, to ensure pleasant non-polluted and ecologically productive ambience and accessible environment with positive effect within adaptation and mitigating climate changes. It is a dynamic, unfinished and open structure. Through vegetation, ecological principles, principles of recycling and social attitude about spontanuous and open occupation, it represents a place of wide public benefit. Its principles, as well as disign elements provide propulsion and continuity, vitality and identity, cultural and economic vibrancy and high urbanity.

On the whole, the strategy behind the idea we are contemplating is: transform available urban fragments (primarily Brownfield) into eco-infill, with a tendency of forming an elaborate network of places designed to combat global climate changes, and, simultaneously, gradually reconstruct and renew existing urban structures outside these areas. These new "eco-networks" are essentially seen as alternative "eco-infrastructure" for a new future urbanity.

Therefore, Eco/Infill strategy should respond to:

- Creation of the new / enhancment of existing ecological habitat through natural resources and its usability through the processes of agriculture and afforestation;

- Increased use of public space, through ecological principles which should guide zoning, construction, management and utilization;

- Preservation of historically significant sites and protection of natural resource;

- Alignment and collision of environmental and urban potentials through social engagement, local community involvement and wider public education on environmental topics;

- Pollution problems through recycling waste and storage, reducing the impact of noise from urban environments, eliminating the presence of chemicals in nature, fostering the use of alternative energy sources;

- Climate change resilience through flood control, bank of natural resources and water consumption, testing and promoting remediation technologies;

- Economic stimulation through public and community cooperation, through the actions of diverse and spontaneous use, maintenance and rehabilitation;

- Restoration of the environment, through the structure of the landscape, cultivation and promotion of micro-locations; 
Having defined the basics, we now turn to exploring urban design possibilities of the post-industrial landscape that surrounds us, defining a productive, eco-active, socially and culturally acceptable and architecturally feasible approach to urban regeneration in general, specifically stressing the need for a fresh and brave approach to the potentials of Brownfield.

\section{WATERFRONTS OF BELGRADE: FOCUSING ON BELGRADE SHIPYARD}

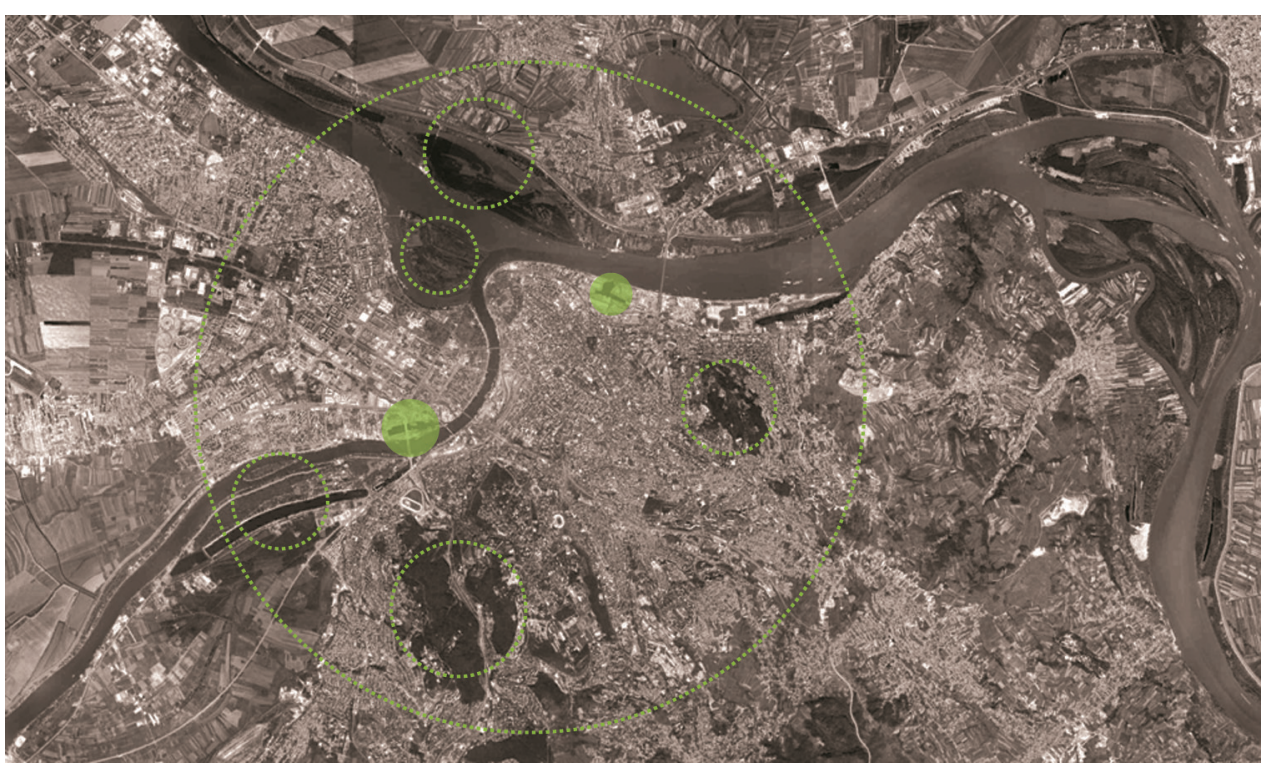

Fig. 9. Waterfronts of Belgrade

Belgrade is a city with potential, one of the larger capitals of the region, standing on the threshold of the European Union and undergoing an intensive process of political, economic and social transition. Similar to other large cities, it was previously an industrial city, but is now increasingly relying on the tertiary sector, promoting itself through its geographical, morphological, and cultural advantages. The consequences of privatization during transition and an exceptionally long and difficult political and economic crisis produced Brownfield and other abandoned spaces of the city centre and along Riverfronts with a complicated proprietary-ownership status, and no realistic guidelines for a much needed regeneration of the city in terms of contemporary problems linked to ecological, social and cultural values.

One of the most intriging and maybe the largest Brownfield on the Sava waterfront in Belgrade, indicating the valuable potential its position offers, especially in relation to infrastructure, neighboring housing capacities and offered activities, is the Belgrade shipyard. The land itself covers an area of $120,000.00 \mathrm{~m} 2$ and is positioned on New Belgrade, on the bank of the Sava River, near the construction of a new bridge over Ada (built in 2012). The construction of the shipyard took place in the period between 1950s 
and 1980s. The shipyard has well organized transportation infrastructure and direct access to the main boulevards. The complex is organized around Aquatoria, and consists of several thousand square meters of warehouse spaces (in the range of $800-1800 \mathrm{~m} 2$ ), offices of various categories and sizes.

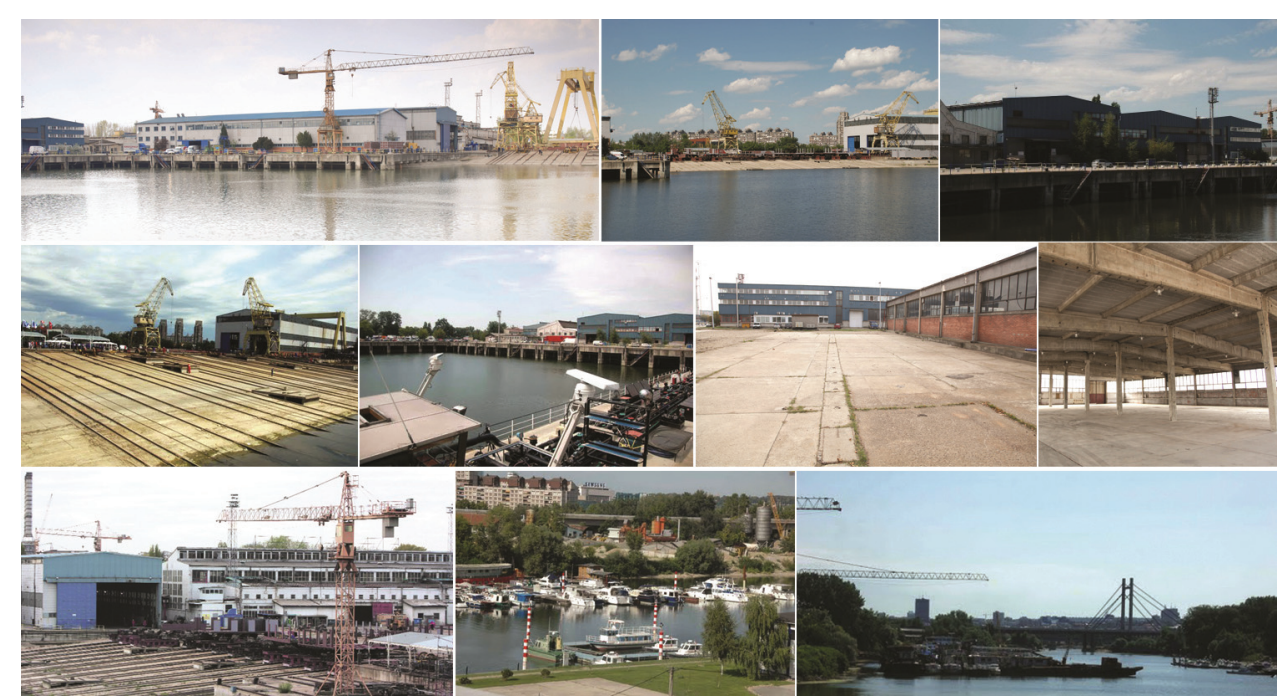

Fig. 10. Belgrade Shipyard

The emidiate vicinity of green city parks in Belgrade (Ada Cignalija, Ratno ostrvo, etc) and shipyard position, both on the river Sava and Danube, present an additional bonus offering possibilities of connecting fragments of potential eco-infill with other parts of Belgrade, forming a centrally positioned eco-network in the very centre of the city.

As a starting point for reactivation of Belgrade riverfront, we propose, as a valuable resource, a good practice found in Houtan Park, Shanghai. Built on a former industrial site, Houtan Park is an autonomous living landscape on Shanghai's Huangpu waterfront. The site is a 14-hectare (34.6 acre) narrow linear strip of land wedged between the riverbank and the city. The objective of the design was to create a "green" Expo, demonstrating green technologies, with the intention of producing a permanent public waterfront that would succeed Expo.
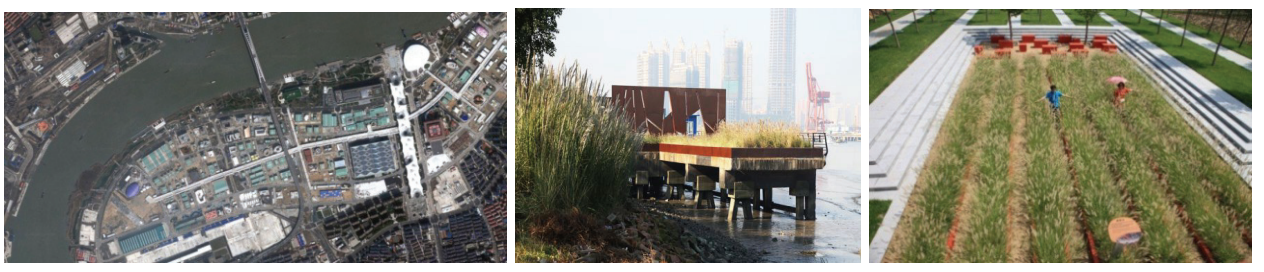

Fig. 11, 12, 13. Shanghai Houtan Park, 2010, Turenscape (http://www.turenscape.com/english/projects/project.php?id=443) 
Houtan Park demonstrates possibilities of incorporating bio-active systems into the contemporary urban environment, where ecological infrastructure can provide multiple services for society and nature, and introduce new ecological water treatment and flood control methods. This unique productive landscape evokes memories of the industrial past, hinting on the possibilities of a future ecological civilization and introducing a new aesthetics based on low maintenance and high performance. This interconnected multifunctional open space needs to be seen as a pleasant net of pedestrian movement and interaction, a web of experiences and choices, backing the development of new life style.

Therefore, in the spirit of Houton park, by forming a network of green spaces as fragments of nature multiplied in process of transforming Brownfield and other degraded areas, we can influence the consequences of existing structures and activities, urban city life in general, and in particular changing climate issues.

\section{TOWARDS A PRODUCTIVE LANDSCAPE: THE BASIC IDEA}

\section{Fragments of nature inserted into abandoned spaces}

Fragments of nature are seen as an antipode to the formerly existing industry. In helping nature to recover through recycling, these fragments generate a new urban environment, a landscape that integrates existing urban structures, influencing an overall ecological and cultural recovery of the contemporary city.

Using previously shown experience of Houghton Park, and previously described and defined ECO-INFILL strategy, two longitudinal zones are recognized framed with border lines intended for urban and river facilities. Urban garden zone on the North side of Aquatoria and Vague Park zone on the south side. While the first one is recognized through elements of recreation, spectacle and urban spirit, as a dynamic and attractive break from everyday routine, the other is seen as an indeterminate, vague space intended to protect the inherited landscape. They interact and collide in the area of the Aquatoria, along which the main points of attraction and vitality are unfolded. These points further emphasize environmental concerns placing a recycling drive, several educational facilities and alike that foster involvement of local community as the best tool of self-sustainability.

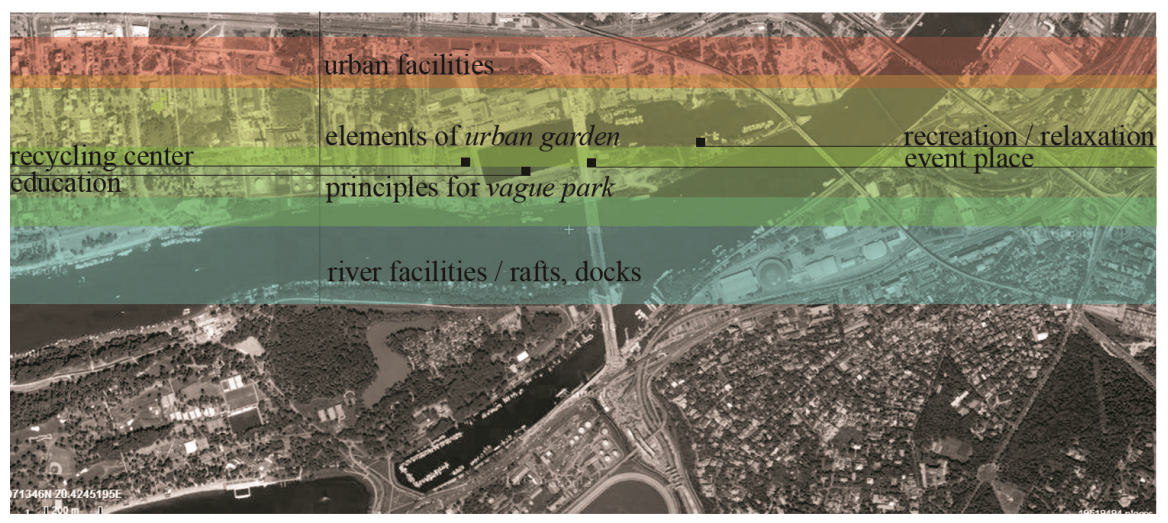

Fig. 14. Belgrade shipyard; intervention / map1 
The main program elements incorporated into this strategy are based on Brownfield infrastructure, which primarily consists of the inherited industrial structure and natural landscapes, then the network of natural resources, namely aquatic and green spaces, structures that foster biodiversity, as well as other structures necessary for a productive eco-system, but also a line of structures identified through the urban needs and the specific context activities that will make this space closer to urban mundane activities and the needs of the local community. Eco-infill strategy for the Belgrade shipyard has been determined through a complex system of functions and activities of the open public space that captivate with its attractiveness and accessibility, forming a park of high urbanity level with specifically emphasized character of past glorified times, as well as ruined memories.

As part of a strategy for the renewall of Belgrade's urban landscape, incorporating fragments of nature in abandoned spaces can produce open public spaces that meet the changing urban life style, and protect and develop the existing character of the landscape. It originates in the interpolation of activities and the architectural language of urban gardens and principles of Vague Park. Confronting nature and city, inherited structures and natural resources, we could shape new public spaces and offer sustainable solutions confronting climate change in a socially acceptable and economically feasible manner.

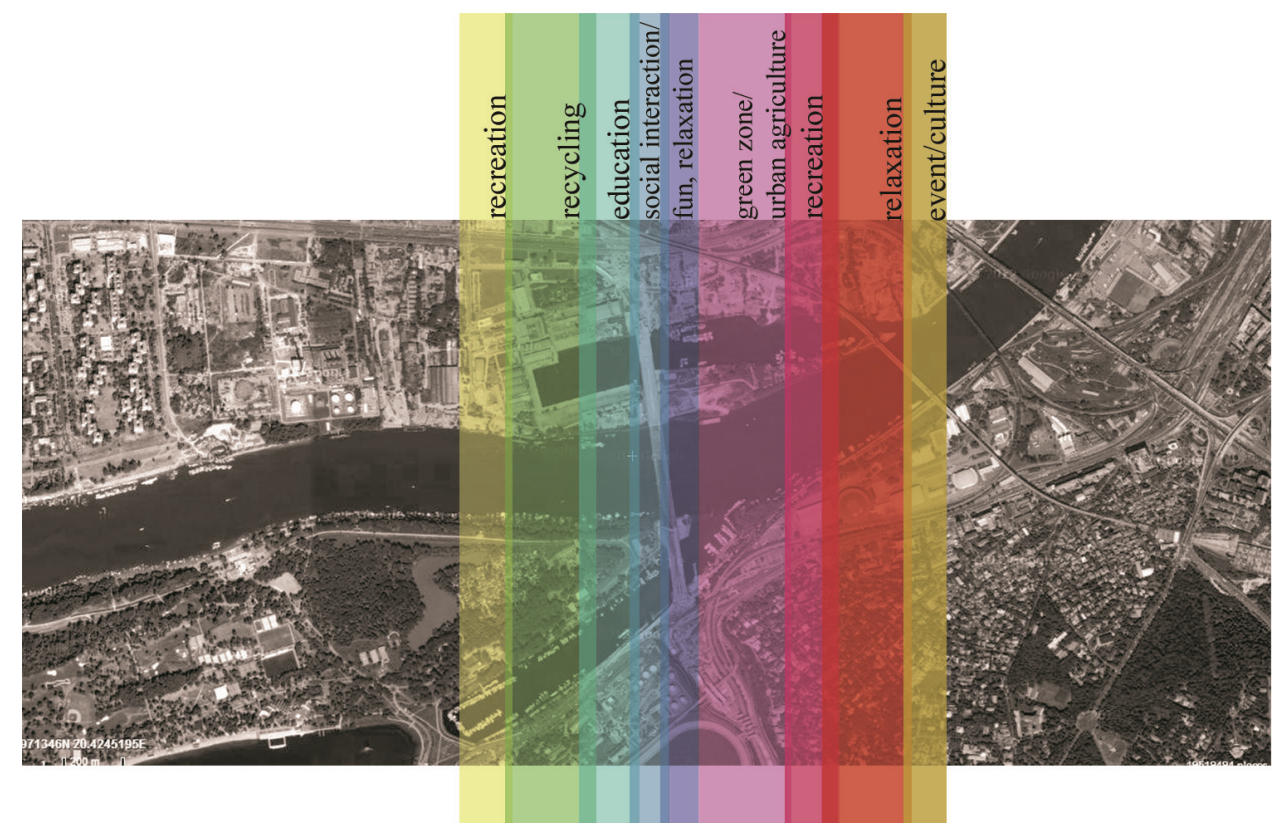

Fig. 15. Belgrade shipyard; intervention / map2

Using the spatial elements of urban gardens and parks vague principles can form different zones, overlapping with each other in the spatial and programmatic sense, respecting the environment, the transition from urban to natural and vice versa, as well as the position and function of the location in relation to the city. Using existing infrastructure, cleaning and healing of the land and the air at this location, which has a great role in mitigating climate change, while planting and cultivating large areas of water helps to reduce 
the emission of harmful radiation, and the overall process of adaptation to climate change. In this way, transformed Shipyard can become a natural habitat, recycling plant, relaxation and recreation space and space for social interaction. Using different spatial and programmatic elements forms zones of microcomfor with different character, which may include urban agriculture, recreation and leisure, enhancing biodevrsity, but also the quality of life in neighborhoods, and the city.

It seems that urban nature leaves enough space for the successful development of recreational activities, making room for a new urbanity, among other things the urban spectacle and a new freedom of choice, while simultaneously protecting our industrial legacy and preserving valuable parts of the urban landscape. At the same time, urban nature can help preserve unpolluted and ecologically productive environments sustaining biodiversity and influencing climate change locally, and eventually globally,

As we have recognized the problem of climate change as the most urgent in urban areas, we look at it from three aspects. The potential for prevention through forming environments of favorable micro-climate along the river, agricultural and areas covered with greenery as to heel the land, then the potential for adaptation in the event of unexpected climatic disasters through water pool, and finally through education on the issues of climate change, through the possibility of participation of individuals, public institutions, establishing communication and awareness about these acute problems in the development of the city.

Sustainability of the eco-infill strategy in case of Belgrade shipyard can be observed in the urban, cultural-historical, socio-economic, but also ecological and climate change aspect.

\section{Urban aspect}

- Integration of Brownfield in the immediate environment,

- Alternative modes of movement, reducing the need for stationary traffic

- Recreation as a part of everyday life,

\section{Cultural-historical aspect}

- Resuscitation of protected monuments,

- Fostering identity and spirit of theplace,

- The cultivation of alternative culture;

\section{Socio-economic aspect}

- Providing a comprehensive and multi-use park,

- Partnership of individuals and municipalities, private and public sectors,

- Increase the quality of life of the local community;

\section{Environmental aspect}

- Conservation of nature ... my yard,

- Environmental programs, how to deal with nature,

- The process of recycling being small in relation to resources (waste, water, soil, air)

- Preservation of ecological values, biodiversity,

- Alternative energy, purification; 
Climate change aspect

- Endurance of nature

- Microclimatic comfort through the vegetation, ventilation, water, land

- Station and management of clean water and soil (filtration, agriculture),

- natural disasters revision of natural use of land, water, rain, wind.

Finally, structuring the new post-industrial landscape of Belgrade as an elaborate network of places for climate change mitigation and adaptation, as well as integral social and technological reinterpretation of the new urbanity, we can create both ecologically sustainable and socially vibrant space. In this way, a new foundation can be formed for the development of gardening and urban farming (Viljoen, 2005), creation of an environment that fosters biodiversity, integration of the production of renewable energies, natural water purification and waste management. The result of these actions would initiate social awareness of the global warming problem, and the importance of mitigation and adaptation of climate changes, combating the harmful effects of urban life on the environment and developing a new awareness of the possibilities offered through integration of the natural environment into the urban landscape.

\section{CONCLUDING REMARKS: \\ FROM FRAGMENTS TO NETWORK: FROM SPACE TO PLACE}

The success and sustainability of these spaces are not always in line with each other. Success means primarily economic benefits, which are difficult to quantify, and primarily involves increasing the quality of the immediate environment of terrain, economic vibrancy and activation in the form of increasing the number of small businesses and local community involvement in the process of maintenance and use, and community benefit, which includes improving the quality of life of local communities, and the inclusion of these areas in modern trends of development through tourism, recreation, culture and education. On the other hand, sustainability implies a continuous process in which the park is constantly evolving, taking into account the natural, ecological benefits and importance in the process of climate change. The success and sustainability seems to break through the eco-infill strategy as an open system that allows a new perspective for the development of city, never completing the process of creation.

In many studies (Ewing et al., 2008; Grimski and Ferber, 2001) it has been pointed out how far the urban centres additionally emphasize negative influence on climate changes and how difficult it is to control or still to predict their development in accordance with the occurred climate changes. In the introductory text of Habitat International 33 from 2009 ., which is completely dedicated to the problem of climate changes in urban environment, six strategic categories on climate changes have been defined, being the science on climate changes, public health, security and preparation for disasters, ground waters management, the quality of fresh water and recycling, feasibility of use of the land, built structure and traffic infrastructure, also with the emphases on biodiversity and eco-system. The same text supports the claim that the local level is the best for the process of reduction of the global heating effects as a level which is closest to the community and to people, and that is why education has a primary role in these parks in the process of climate changes. 
It seems that improvement of quality of terrain of eco-infill strategy may be included in all of the above categories, through preservation of urban green areas, namely: effective control of the immediate environment pollution, perennial vegetation and its usefulness in terms of energy conservation through cooling and shading, reducing the effects of storm, creating a natural habitat and space for relaxation, recreation and social interaction (Moffat, Hutchings, 2007), as well as the preservation of micro location value and environment biodiversity, namely not interfering with the eco-system (Harrison, Davies, 2002). In this way, the main principles of adaptation and improvement of urban spaces to climate changes have been met.

Finally, Belgrade shipyard is really not the point of this paper but only a good, perhaps exceptionally good example of possibilities of interconnecting patchwork eco-infill into an integrated and elaborate system capable of combating climate change and, at the same time, transforming the urban landscape to meet the needs and expectations of a new urbanity, of an emerging multidimensional life style that is developing.

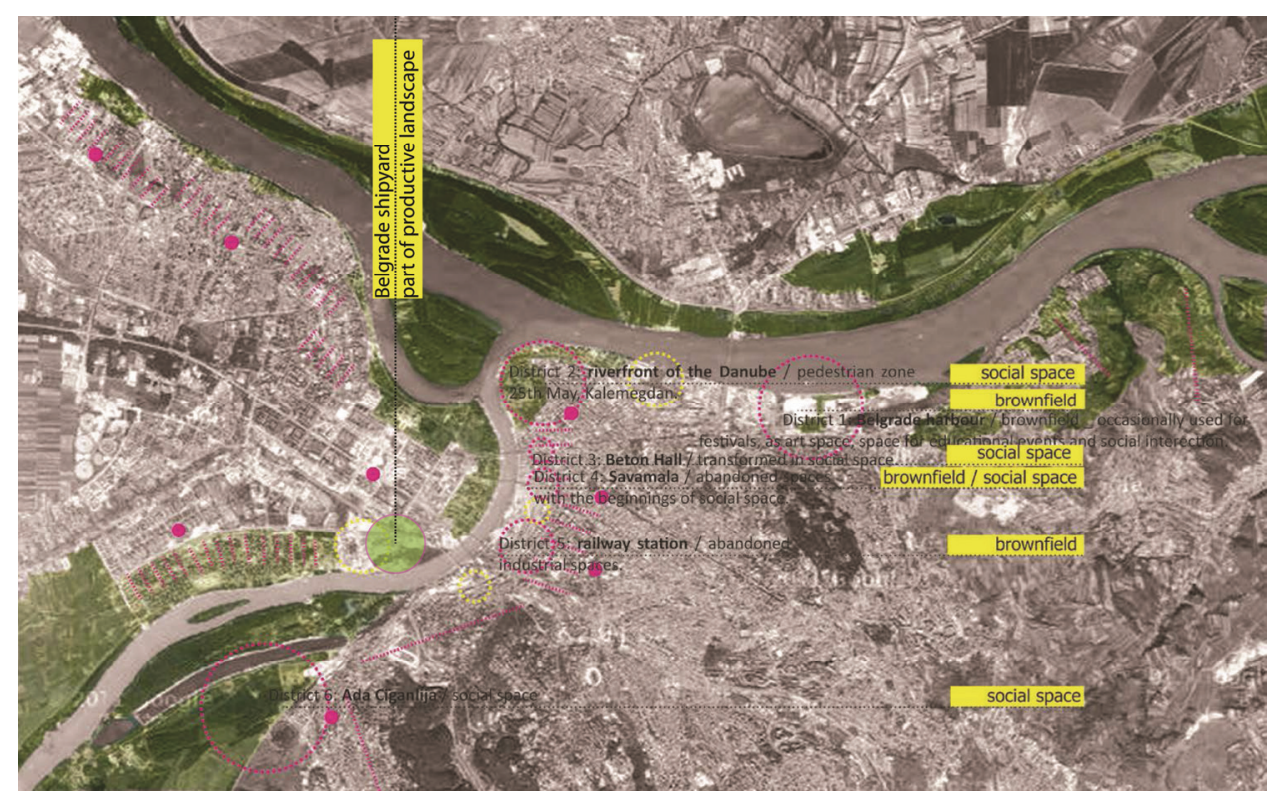

Fig. 16. Belgrade shipyard as part of the productive landscape / Belgrade waterfront

We are, essentially, talking about concepts, about methods of exploring possibilities of combating climate change through the "regular" process of urban transformation and regeneration aimed at solving urban discontinuity (Brownfield and other degraded urban land), and upgrading and recreating social and cultural conditions for everyday city life. We are suggesting a combined eco - cultural approach to be applied, a technique of interconnecting fragmented possibilities of urban renewal, thus advocating a long term strategy in which we aim to gradually develop systems, preferably physically connected and dense interactive networks by using various architectural and urban design tools. This eco-infill would, of course, be a major instrument in combating climate change, but it would also help in connecting and combining various parts of the city making it whole, and initiate an indirect transformation and renewal of previously built up areas, creating a modern eco-sensitive framework for urban regeneration. 


\section{REFERENCES}

1. A.J. Moffat, T.R. Hutchings, "Greening Brownfield Land," in T. Dixon, M. Raco, P. Catney and D. Larner (Eds), Sustainable Brownfield Regeneration: Livable Places for Problem Space, Oxford: Blackwell Publishing, 2007, pp. 143-176.

2. A. M. Moya Pellitero, E. Türkyilmaz, C. C. Türkyilmaz and J. da Silva Eliziário, J. "The design of a productive landscape Barcelona TresTurons Park, a case study", The New Urban Question - Urbanism beyond Neo-Liberalism, The 4th International Conference of the International Forum on Urbanism (IFoU), Amsterdam/Delft, 2009, pp. 909-918.

3. A. Viljoen (Ed.), CPULS, Continuous Productive Urban Landscapes, designing urban agriculture for sustainable cities, Oxford: Architectural Press, 2005.

4. A. Yarinski, "New York City 2106: Back to the Future", in Places, Climate Change and Place, vol. 20, number 2, New York: Places Foundation, 2008, pp. 14-18.

5. C. Choguil (Ed.), Habitat international, vol. 33, issue 3, Amsterdam: Elsevier, 2009.

6. D. Grimski and U. Ferber, "Urban Brownfields in Europe", in Land Contamination and Reclamation, vol. 9, no. 1, London: EPP publication, 2001, pp.143-148.

7. E.M. Hamin and N. Gurran, "Urban form and climate change: Balancing adaptation and mitigation in U.S. and Australia", in Habitat International, vol. 33, issue 3, Amsterdam: Elsevier, 2009, pp. 238-245.

8. I. de Sola Morales, "Terrain Vague", in Anyplace, C. Davidson (Ed), Michigen: University of Michigen, Anyone Corporation, 1995, pp. 118-123.

9. K. Kamvasinou, "Vague parks: the politics of late twentieth-century urban landscapes", in Architectural Research Quarterly, vol 10, no 3/4, Cambridge: Cmbridge Press, 2006, 255-262.

10. K.J. Doick, G. Sellers, V. Castan-Broto and T. Silverthorne, "Understanding success in the context of brownfiled greening projects: The requirement for outcome evaluation in urban greenspace success assessment”, in Urban Forestry \& Urban Greening, vol. 8, issue 3, Frankfurt: Elsevier GmbH, 2009, pp. 163-178. http://www.sciencedirect.com/science/article/pii/S1618866709000338

11. L. Loures, D. Horta, A. Santos and T. Panagopoulos, "Strategies to Reclaim Derelict Industrial Areas", in Wseas Transaction on Environment and Development, vol.2, issue 5, Southampton: WIT Press, 2006, pp. 181-188. http://w3.ualg.pt/ tpanago/public/industrial.pdf

12. R. Lafortezza, G. Sanesi, B. Pace and R.C. Corry. "Planning for the rehabilitation of Brownfield sites: a landscape ecological perspective", Brownfield Sites II, Donati, A. and C. Rossi, C.A. Brebbia, (Eds), Southampton: WIT Press, 2004, pp. 21-30.

13. R.Ewing, K. Bartholomew, S. Winkelman, J. Walters and D. Chen. Growing Cooler: the evidence on urban development and climate change, Washington DC: Urban Land Institute, 2008.

14. T. Dixon, M. Raco, P. Catney and D. Larner (Eds.), Sustainable Brownfield Regeneration: Livable Places for Problem Space, Oxford: Blackwell Publishing, 2007.

\section{"ECO-INFILL" KAO ALTERNATIVNA STRATEIJA ZA POST- INDUSTRIJSKI PEJZAŽ U SVETLU KLIMATSKIH PROMENA: SLUČAJ BEOGRADSKOG BRODOGRADILIŠTA}

\section{Ana Nikezić, Nataša Janković}

U ovom trenutku, i pod okolnostima koje nas okružuju, prepoznali smo kao globalni izazov problem klimatskih promena, i uopšte, ekološku neravnotežu u gradovima. Kao jedan od odgovora na ovakav izazov, predlažemo mogućnost primene strategije "Eko-ispune" (fragmenti prirode inkorporirani u napušteno okruženje) kao održivu, donekle "alternativnu", strategiju urbanog razvoja.

Savremena matrica post-industrijskog urbanog pejzaža obiluje većim i manjim fragmentima napuštenih prostora, koje je potrebno uključiti u teksturu grada. Beograd je grad sa potencijalom, jedan od većih gradova u regionu, pozicioniran na pragu Evropske unije, ali istovremeno grad koji prolazi kroz intenzivan proces političke, ekonomske i društvene tranzicije. Slično drugim velikim gradovima, koji su ranije bili industrijski, sada se sve više oslanja na tercijarni sektor, promovišući sebe kroz geografske, morfološke i kulturne karakteristike. Posledice privatizacije 
tokom tranzicije $i$ izuzetno dug $i$ težak period političke $i$ ekonomske krize proizveli su brojne braunfild $i$ druge napuštene prostore u gradskim centrima $i$ duž obala reka, koje karakteriše komplikovan vlasničko-imovinski status, pri čemu ne postoje konkretne smernice za preko potrebnom regeneracijom grada u pogledu odgovora na savremene izazove u vezi sa ekološkim, društvenim i kulturnim vrednostima.

Ovaj rad definiše principa na osnovu kojih je moguća transformasati napuštene prostore. pri čemu kao studiju sliučaja za ispitivanje mogućnosti primene ovih principa u Beogradu ispituje primer Beogradskog brodogradilišta na reci Savi. Ako prihvatimo prethodno postavljene opšte stavove, ovi prostori mogu postati ključni u razvoju strategije za ublažavanje efekata $i$ prilagođavanje na klimatske promene. Iako su benefiti ovakvih intervencija prvenstveno usmereni na suočavanje sa klimatskim promenama, oni imaju za cilj $i$ da unaprede kvalitet života, da ponude nove stilove života, $i$ potencijalno utiču na sve aspekte urbanog života, s obzirom da je primenom"eco-infill" strategije nastaju aktivni javni prostori.

Ključne reči: post-industrijski pejzaž,klimatske promene, Beogradsko brodogradilište 